\title{
Physiological responses to acute temperature increase in European eels Anguilla anguilla infected with Anguillicola crassus
}

\author{
Matthew J. Gollock ${ }^{1,2, *}$, Clive R. Kennedy ${ }^{1}$, J. Anne Brown ${ }^{1}$ \\ ${ }^{1}$ School of Biological and Chemical Sciences, Hatherly Laboratories, University of Exeter, Prince of Wales Road, Exeter, \\ Devon EX4 4PS, UK \\ ${ }^{2}$ Present address: Ocean Sciences Centre, Memorial University of Newfoundland, St John's, \\ Newfoundland A1C 5S7, Canada
}

\begin{abstract}
The swimbladder parasite, Anguillicola crassus has infected, and spread rapidly, through European eel Anguilla anguilla (L.) populations over the past 20 to 25 yr. Our aim in the present studies was to elucidate whether the presence of $A$. crassus in these eels alters their rapid physiological responses to an acute temperature increase, compared to the response of uninfected fish. Both infected and uninfected fish showed significant increases in plasma cortisol after $2 \mathrm{~h}$ at a raised environmental temperature with increased plasma glucose after $6 \mathrm{~h}$. However, infected eels exhibited a slight lag in glucose mobilisation, which may be due to the metabolic cost of harbouring a sanguiverous parasite. Both infected and uninfected fish showed a significant increase in haematocrit after $6 \mathrm{~h}$ of temperature elevation, but only uninfected fish exhibited a significant increase in haemoglobin at this point. However, there were no significant changes in mean erythrocyte haemoglobin concentration in either group. Our results suggest that acute temperature increase alone is unlikely to cause significant mortality of A. crassus-infected European eels; however, the effects of chronic increases in temperature in combination with other factors such as toxicants and hypoxia requires examination.
\end{abstract}

KEY WORDS: Anguillicola crassus · Anguilla anguilla · Temperature · Stress · Cortisol · Glucose Resale or republication not permitted without written consent of the publisher

\section{INTRODUCTION}

The nematode Anguillicola crassus was introduced into Europe from the Far East in the early 1980s when Anguilla japonica was imported for aquacultural purposes, which resulted in infection of wild populations of European eel Anguilla anguilla (De Charleroy et al. 1990). While the Japanese eel maintains low numbers of adult $A$. crassus $(<10)$ in the swimbladder without obvious pathological effects, naïve $A$. anguilla can be infected with as many as 50 mature worms. Infection involves ingestion of the larval stage, either in an intermediate or paratenic host (Kennedy \& Fitch 1990), and migration of the larva through host tissues to the swimbladder lumen causing significant tissue damage (Molnár et al. 1993, Würtz et al. 1996, Würtz \&
Taraschewski 2000, Lefebvre et al. 2002), which has been reported to cause an increase in cortisol levels (Sures et al. 2001). However, our investigations of wild eels, sampled monthly over an 18 mo study, showed no major, consistent differences in the hormonal or metabolic status of eels carrying up to 15 blood-feeding adult $A$. crassus in their swimbladder lumen and as many as 25 additional larvae in the swimbladder wall (Kelly et al. 2000) compared to uninfected eels. Furthermore, there was a lack of correlation between $A$. crassus loading in the lumen or larvae in the swimbladder and the measured physiological indices of stress (plasma cortisol, plasma glucose, haematocrit) (Kelly et al. 2000). While these results suggest possible adaptation to chronic anguillicolosis, recent studies that have focused on the cortisol (glucocorticoid) receptors 
(Greenwood et al. 2003) indicate that chronic cortisol stimulation can lead to autoregulation of the receptors and cellular responses that favour tissue responsiveness (Vijayan et al. 2003). Thus, the sensitivity of $A$. crassus-infected eels compared to uninfected eels to additional stressors is not readily predictable.

There is evidence to suggest that acute temperature increases may have a pronounced effect on eels suffering from anguillicolosis. In particular, 250 tonnes of European eels, at least $\sim 65 \%$ of which were infected with Anguillicola crassus, died in the Western basin of Lake Balaton, Hungary, after water temperatures increased to $28^{\circ} \mathrm{C}$ (Molnár et al. 1991, Bálint et al. 1997). Similar, though less pronounced, mortalities were also reported in the Western basin of Lake Balaton in the summers of 1992 and 1995 (Molnár 1993, Bálint et al. 1997) and in the Vranov Reservoir, Czech Republic, in 1994 (Baruš \& Prokeš 1996). However, eels infected with $A$. crassus living in a thermal effluent at 8 to $10^{\circ} \mathrm{C}$ above seasonal norm appeared to suffer no serious changes in haematological parameters (Höglund et al. 1992). Thus, an acute increase in temperature, rather than prolonged exposure to high temperatures, to which eels might acclimate, could be a potential cause of mortalities of A. crassus-infected eels.

Due to the ectothermic nature of most teleost fish, the surrounding environment dictates body temperature and fish become vulnerable to unseasonal thermal changes that may occur. Acute temperature increases have been shown to initiate both endocrine (primary), and secondarily-induced osmoregulatory and metabolic effects in many species of fish. For example, acute temperature elevation has been reported to cause increased plasma cortisol in rainbow trout Oncorhynchus mykiss, cutthroat trout O. clarki clarki, Chinook salmon O. tshawytscha, Pagothenia borchgrevinki (Ryan 1995) and tilapia Oreochromis mossambicus (Ackerman et al. 2000, Basu et al. 2001, Mesa et al. 2002). Cortisol is known to stimulate both metabolic substrate mobilisation and ionoregulatory changes during stress (Wendelaar Bonga 1997). For example, O. clarki clarki exhibits a significant increase in plasma glucose levels after exposure to heat shock, and $O$. tshawytscha shows raised levels of both plasma glucose and lactate (Ackerman et al. 2000, Mesa et al. 2002). Similarly, olive flounder Paralichthys olivaceus and black rockfish Sebastes schlegeli exhibit increased plasma glucose and lactate after a $4 \mathrm{~h}$ exposure to elevated temperature (Lee et al. 2001). As yet, however, there has been little if any work carried out on the effect of acute temperature change on parasitised fish.

Our laboratory study therefore aimed to compare the acute physiological responses of Anguillicola crassus- infected eels and the responses of uninfected eels when exposed to an imposed thermal regime with a rapid increase in water temperature from 11 to $28^{\circ} \mathrm{C}$ in a 6 h study.

\section{MATERIALS AND METHODS}

Experimental procedure. European eels Anguilla anguilla (L.) were captured from field sites by electrofishing using a pulse D.C. (direct current) unit (peak power output $2.8 \mathrm{~kW}$ ). Uninfected fish (mean mass $=53.6 \mathrm{~g}$ ) were caught from the River Otter, Devon, UK (Ordnance Survey Ref. SY 077 818), where less than $1 \%$ of eels are infected with Anguillicola crassus (Kelly et al. 2000, Gollock et al. 2004). Previous attempts at artificial infection of eels from this site with $A$. crassus had an extremely low success rate (Kelly 1998) and therefore, for the present studies, wild infected eels were required. At the time of this study there were no sites available that would provide a pool of both infected and uninfected eels. Infected eels (mean mass $=87.5 \mathrm{~g}$ ) were therefore obtained from Slapton Ley, Devon (Ordnance Survey Ref. SX 825 425), a site that has shown a relatively constant level of anguillicolosis (>99\% eels infected) for the past $9 \mathrm{yr}$ (Ashworth \& Kennedy 1999, Kelly et al. 2000, Gollock et al. 2004). All eels were acclimated to identical water and tank conditions for a minimum of $3 \mathrm{wk}$ before experimental manipulations. This period also allowed recovery from electrofishing and transportation and handling (Gollock 2002). Eels were maintained in plastic tanks, supplied with a constant flow of dechlorinated, aerated water at $11^{\circ} \mathrm{C}$ $\left( \pm 1^{\circ} \mathrm{C}\right)$, with a $12 \mathrm{~h}: 12 \mathrm{~h}$ light:dark cycle. After acclimation, resting levels of all parameters measured in the study, as in previous studies using eels from the 2 sites (Gollock et al. 2004) were not statistically different.

After acclimation, 12 eels were quickly transferred to individual $4.5 \mathrm{l}$ tanks in a $150 \mathrm{l}$ closed system with water being re-circulated through a filter to remove ammonia. This procedure was carried out on 5 separate occasions to yield a total of 30 uninfected eels and 30 infected eels. The system was initially maintained at $11^{\circ} \mathrm{C}\left( \pm 1^{\circ} \mathrm{C}\right)$ using a heater-cooler unit (RC $1400 \mathrm{G}$, Grant) and eels were given at least $6 \mathrm{~d}$ to recover from the transfer before rapidly raising the temperature of the water. All 5 experimental runs were started at the same time to minimise the effect of diurnal variations on physiological parameters. Basal samples at $11^{\circ} \mathrm{C}$ $\left( \pm 1^{\circ} \mathrm{C}\right)$ were collected from 10 uninfected eels and 10 infected eels.

To achieve a rapid increase in water temperature, the maximal heating by the circulating heater unit was 
applied. Temperature rose from the initial $11^{\circ} \mathrm{C}\left( \pm 1^{\circ} \mathrm{C}\right)$ to $\sim 24$ to $25^{\circ} \mathrm{C}$ after $3 \mathrm{~h}$, before beginning to plateau. After $2 \mathrm{~h}$, when water temperature was $22^{\circ} \mathrm{C}\left( \pm 1^{\circ} \mathrm{C}\right)$, blood samples were taken from 10 uninfected fish and 10 infected fish. Finally, a further group of blood samples were taken at $6 \mathrm{~h}$, when the temperature was $28^{\circ} \mathrm{C}\left( \pm 1^{\circ} \mathrm{C}\right)$.

Blood sampling. To obtain blood samples, eels were removed from their tanks using a net and immersed in anaesthetic (Benzocaine; $1 \mathrm{~g} \mathrm{l}^{-1}$; ethyl 4-aminobenzoate: Sigma). After $1 \mathrm{~min}$, blood samples were rapidly obtained from the caudal vasculature as in previous studies (Gollock et al. 2004) using pre-heparinised (28 $\mathrm{mg} \mathrm{ml}^{-1}$ ammonium heparin: Sigma) 23 gauge (G) needles (Microlance) and $2 \mathrm{ml}$ syringes (Plastipak, Type B-D). Fish were then killed by immersion in a lethal concentration of anaesthetic to enable epidemiological investigations.

Epidemiology. The swimbladder was removed, and Anguillicoa crassus present in the lumen were removed and counted under a dissecting microscope. The swimbladder was then placed between 2 sheets of glass and larval A. crassus identified and counted under a dissecting microscope. On the rare occasion of infection of River Otter eels, blood samples were rejected from further analysis.

Blood haematocrit and haemoglobin. Haematocrit was measured immediately after blood sampling, in duplicate, in pre-heparinized microhaematocrit tubes, centrifuged at $12250 \times g$ for 5 min (Gelman Hawksley haematocrit centrifuge), and packed red cell volume (\%) determined using a haematocrit reader. Haemoglobin concentration (g $100 \mathrm{ml}^{-1}$ ) was determined spectrophotometrically using an assay kit (Sigma). Mean corpuscular haemoglobin concentration (MCHC) was calculated from:

$$
\begin{gathered}
\text { MCHC (g } \left.100 \mathrm{ml}^{-1}\right)=\left[\text { haemoglobin }\left(\mathrm{g} 100 \mathrm{ml}^{-1}\right) /\right. \\
\text { haematocrit }(\%)] \times 100
\end{gathered}
$$

Plasma glucose and cortisol. After removal of blood samples for haematocrit and haemoglobin, samples were centrifuged ( $3 \mathrm{~min}, 11000 \times g_{\text {; }}$ MSE, Microcentaur) and plasma aliquoted and frozen for later determination of plasma cortisol and glucose levels. Plasma samples were kept at $-20^{\circ} \mathrm{C}$ until required. Plasma glucose concentrations were determined spectrophotometrically (Boehringer Mannheim; kit MPR3) and plasma cortisol concentrations measured by radioimmunoassay (RIA) (Brown et al. 2001, Gollock et al. 2004).

Statistical analysis. All data were tested for normality or transformed to achieve normality. Levene's test was applied to determine equality of variances before analysis by ANOVA with post hoc analysis by Tukey's Honestly Significant Difference (HSD) where there were equal variances or by Games Howell where variances were unequal. Differences between infected and uninfected eels were identified by Student's $t$-tests.

\section{RESULTS}

Both Anguillicola crassus-infected and uninfected eels exhibited a rise in plasma cortisol concentrations during exposure to a rising water temperature (Fig. 1). In both groups there was a significant rise in plasma cortisol concentrations after $2 \mathrm{~h}$ of rising water temperature to reach $22 \pm 1^{\circ} \mathrm{C}$ compared to the initial plasma cortisol concentrations at $11^{\circ} \mathrm{C}$ $\left( \pm 1^{\circ} \mathrm{C}\right)$ at time $0 \mathrm{~h}$ (Fig. 1), with no significant apparent difference in the plasma cortisol of eels infected with $A$. crassus and uninfected eels. Despite the further rise in temperature over the following $4 \mathrm{~h}$, after $6 \mathrm{~h}$, when water temperature had reached $28^{\circ} \mathrm{C}$, plasma cortisol concentrations of uninfected eels had recovered to levels not significantly different from initial levels (Fig. 1). In contrast, in eels infected with A. crassus, plasma cortisol remained significantly elevated compared to levels at time $0 \mathrm{~h}$, although not significantly elevated compared to uninfected eels.

Both Anguillicola crassus-infected and uninfected eels showed a significant elevation of plasma glucose concentrations after $6 \mathrm{~h}$ exposure to high water temperature (Fig. 2). However, the pattern of response suggested a more rapid rise in plasma glucose in uninfected eels with plasma glucose at $2 \mathrm{~h}$ at an intermediate level between basal concentrations and those after $6 \mathrm{~h}$, but not statistically different from either time point.

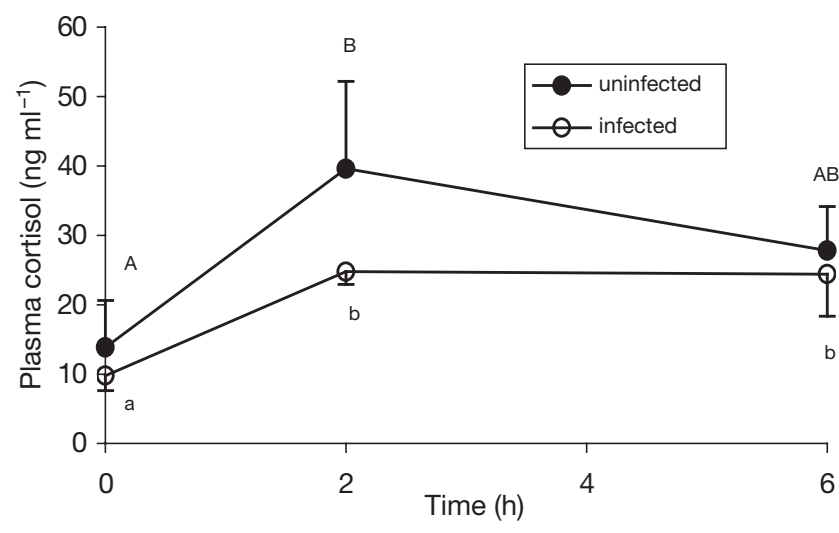

Fig. 1. Anguilla anguilla infected with Anguillicola crassus. Plasma cortisol concentrations in infected European eels and uninfected eels exposed to an acute increase in water temperature from 11 to $28^{\circ} \mathrm{C}$. Different letters indicate a significant difference between time-points within groups; A, B: A. crassus-infected fish; a, b: uninfected eels 


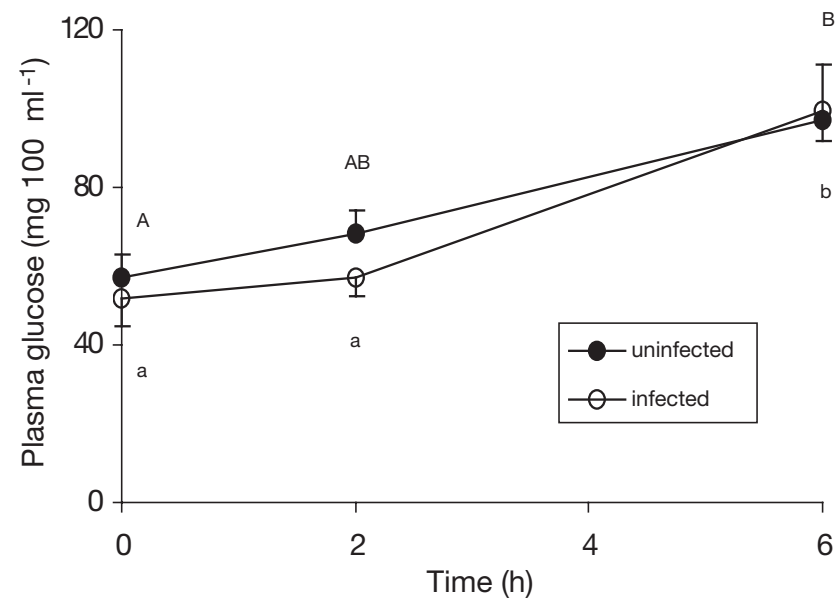

Fig. 2. Anguilla anguilla infected with Anguillicola crassus. Plasma glucose concentrations in infected European eels and uninfected eels exposed to an acute increase in water temperature from 11 to $28^{\circ} \mathrm{C}$. Different letters indicate a significant difference between time-points within groups; A, B: A. crassus-infected fish; a, b: uninfected eels

The slower rise in plasma glucose in A. crassusinfected fish resulted in plasma glucose concentrations at $2 \mathrm{~h}\left(22^{\circ} \mathrm{C}\right)$ that were not significantly different from basal levels but that were significantly less that those after $6 \mathrm{~h}\left(28^{\circ} \mathrm{C}\right)$ (Fig. 2).

Uninfected eels showed a significant increase in both haematocrit and haemoglobin levels after $6 \mathrm{~h}$ exposure to elevated temperatures (when temperature had reached $28^{\circ} \mathrm{C}$ ), compared to the levels in both the initial and $2 \mathrm{~h}$ samples (Table 1). In contrast, although haematocrit was significantly elevated in Anguillicola crassus-infected eels after $6 \mathrm{~h}$ (as in uninfected eels), haemoglobin concentrations were not significantly increased during exposure to high temperatures at either time point. There were no significant changes in $\mathrm{MCHC}$ in either A. crassus-infected or uninfected fish (Table 1).

\section{DISCUSSION}

Our studies employed an experimental approach to systematically raise water temperature and compare the physiological responses of Anguillicola crassusinfected eels to those of uninfected eels. The results indicate that an acute increase in water temperature from 12 to $28^{\circ} \mathrm{C}$, over a period of $6 \mathrm{~h}$, has similar effects on uninfected and A. crassus-infected eels but with some apparent differences in the rate of responses.

The sanguiverous nature of Anguillicola crassus might be predicted to limit the ability to increase haematocrit during temperature stress. However, after $6 \mathrm{~h}$ at elevated temperatures, haematocrit reached 32.2 and $27.5 \%$ in uninfected and infected eels respectively, with no significant difference between the 2 groups and furthermore no correlation between haematocrit and parasitic load was apparent.

The parallel increases in haematocrit and haemoglobin in uninfected eels after $6 \mathrm{~h}$ of raised water temperature, in the absence of significant changes in $\mathrm{MCHC}$, suggests an increase in the number of circulating erythrocytes without significant erythrocytic swelling. In contrast, Anguillicola crassus-infected fish showed a significant increase in haematocrit, not dissimilar from that in uninfected fish, but the increase in haemoglobin concentration was not statistically significant ( $\mathrm{p}<0.059$ ). However, MCHC was unaffected by the temperature increase in either group of eels; thus, the lack of a significant increase in haemoglobin concentration, despite the significant increase in haematocrit in A. crassus-infected eels does not appear to be due to erythrocyte swelling. An alternative explanation is that ion losses occurred and led to reduced plasma volume (Milligan \& Wood 1982). However, the major cause of increased haematocrit in both infected and uninfected eels is likely to have been a splenic release of stored erythrocytes induced by circulating catecholamines (Gaullagher \& Farrell 1998). Cate-

Table 1. Anguilla anguilla infected with Anguillicola crassus. Haematocrit, haemoglobin and mean corpuscular haemoglobin concentration (MCHC) levels in infected and uninfected fish during exposure to an acute increase in temperature. Different superscript letters indicate a significant difference $(\mathrm{p}<0.05)$ between time-points within each group. There were no significant differences between groups at any time-points in any parameter

\begin{tabular}{|c|c|c|c|c|}
\hline \multirow[t]{2}{*}{ Parameter } & \multirow[t]{2}{*}{ Eel group } & \multicolumn{3}{|c|}{ Time (h) } \\
\hline & & 0 & 2 & 6 \\
\hline Haematocrit (\%) & $\begin{array}{l}\text { Uninfected } \\
\text { Infected }\end{array}$ & $\begin{array}{l}23.01 \pm 1.15^{\mathrm{a}} \\
23.04 \pm 0.79^{\mathrm{a}}\end{array}$ & $\begin{array}{l}25.62 \pm 1.15^{\mathrm{a}} \\
26.80 \pm 1.37^{\mathrm{ab}}\end{array}$ & $\begin{array}{l}32.19 \pm 2.25^{b} \\
27.50 \pm 1.82^{b}\end{array}$ \\
\hline Haemoglobin (g $100 \mathrm{ml}^{-1}$ ) & $\begin{array}{l}\text { Uninfected } \\
\text { Infected }\end{array}$ & $\begin{array}{l}6.51 \pm 0.37^{\mathrm{a}} \\
6.09 \pm 0.44^{\mathrm{a}}\end{array}$ & $\begin{array}{l}6.99 \pm 0.82^{\mathrm{a}} \\
6.63 \pm 0.58^{\mathrm{a}}\end{array}$ & $\begin{array}{l}8.87 \pm 0.72^{\mathrm{b}} \\
7.78 \pm 0.46^{\mathrm{a}}\end{array}$ \\
\hline $\mathrm{MCHC}\left(\mathrm{g} 100 \mathrm{ml}^{-1}\right)$ & $\begin{array}{l}\text { Uninfected } \\
\text { Infected }\end{array}$ & $\begin{array}{l}28.81 \pm 2.25^{\mathrm{a}} \\
26.30 \pm 1.47^{\mathrm{a}}\end{array}$ & $\begin{array}{l}27.10 \pm 2.81^{\mathrm{a}} \\
25.00 \pm 2.05^{\mathrm{a}}\end{array}$ & $\begin{array}{l}27.28 \pm 0.69^{\mathrm{a}} \\
28.23 \pm 1.87^{\mathrm{a}}\end{array}$ \\
\hline
\end{tabular}


cholamines induce minimal erythrocyte swelling in anguillids (Perry \& Reid 1992), in contrast to their significant effect and resultant reduction in $\mathrm{MCHC}$ in other species (Nikinmaa \& Salama 1998). This is in line with our findings of a stable $\mathrm{MCHC}$ in both groups of eels exposed to temperature stress.

Eels exposed to an increase in temperature have been shown to elevate oxygen consumption, indicating temperature-driven increases in metabolic rates (Sébert et al. 1995). There is evidence to suggest that eels may preferentially use glucose as an energy substrate, which is unusual amongst teleosts (Kieffer et al. 1998, Legate et al. 2001). In our studies, plasma glucose concentrations were significantly increased in both groups of eels exposed to the rising water temperatures although the Anguillicola crassus-infected fish appeared to show a delay in glucose mobilisation with no significant elevation until the $6 \mathrm{~h}$ sample point. The delayed rise in plasma glucose may reflect a higher rate of metabolism causing high glucose turnover due to the metabolic strain of parasitism, as was suggested for a similar absence of a glucose response in rainbow trout Oncorhynchus mykiss exposed to hypoxic stress (Wright et al. 1989). Our previous studies suggest increased glucose utilisation in A. crassus-infected eels during stress imposed by netting and aerial exposure (Gollock et al. 2004). However, during netting and aerial exposure there was no evidence of delayed glucose mobilisation in A. crassus-infected eels (Gollock et al. 2004). Cortisol is known to stimulate substrate mobilisation for glucose production, the primary substrates being amino acids (Milligan 1997, Mommsen et al. 1999), and the hormone remained elevated at the $6 \mathrm{~h}$ sample point in infected fish whereas in uninfected fish, cortisol had returned to within basal levels. However, cortisol and glucose concentrations were not significantly different between $A$. crassus-infected and uninfected eels at any of the time points, and thus the responses require further investigation. If a more prolonged cortisol response does occur in A. crassusinfected fish, and is sustained over a prolonged period, then this would not only have an effect on the metabolism of the fish, but also cause immunosuppression, which would be likely to have important effects on resistance to infection by other pathogenic organisms (Maule \& VanderKooi 1999).

Overall, our study indicates that the presence of Anguillicola crassus does not induce major changes in the acute physiological responses of eels to short-term increases in water temperature. However, this does not discount acute diel temperature change as a factor in the mass mortalities that have been reported in $A$. crassus-infected eels in Lake Balaton and the Vranov resevoir. Long-term exposure to these daily fluxes may be more detrimental to infected fish, which are poten- tially suffering a metabolic challenge, harbouring a large number of sanguiverous parasites. Equally, the experiment does not rule out other factors, such as high levels of pesticides or low oxygen levels, which have also been suggested to be involved in these mass eel mortalities (Molnár et al. 1991, Molnár 1993, Bálint et al. 1997). Further experimental studies of the influence of environmental variables on A. crassus-infected eels are therefore required to more fully understand the impact on wild populations.

Acknowledgements. M.J.G. was in receipt of a studentship from NERC (Natural Environment Research Council) during this work. We are grateful to Drs. P. Ingleton and D. Kime (University of Sheffield) for the kind gift of the antisera used in the cortisol radioimmunoassay (RIA), and to The Whitley Wildlife Conservation Trust for allowing us to obtain fish from Slapton Ley and the Clinton Devon Estates for permission to capture fish in the River Otter. Special thanks are due to J. Shears and P. Shears for their invaluable technical support, and to E. S. Quabius for help in setting up the cortisol RIA.

\section{LITERATURE CITED}

Ackerman PA, Forsyth RB, Mazur CF, Iwama GK (2000) Stress hormones and the cellular stress reponse in salmonids. Fish Physiol Biochem 23:327-336

Ashworth ST, Kennedy CR (1999) Density-dependent effects on Anguillicola crassus (Nematoda) within its European eel definitive host. Parasitology 118:289-296

Bálint T, Ferenczy J, Kátai F, Kiss I and 7 others (1997) Similarities and differences between the massive eel (Anguilla anguilla L.) devastations that occurred in Lake Balaton in 1991 and 1995. Ecotoxicol Environ Saf 37:17-23

Baruš B, Prokeš M (1996) Length-weight relations of uninfected and infected eels (Anguilla anguilla) by Anguillicola crassus. Folia Zool 45:183-189

Basu N, Nakano T, Grau EG, Iwama GK (2001) The effects of cortisol on heat shock protein 70 levels in two species of fish. Gen Comp Endocrinol 124:97-105

Brown JA, Moore WM, Quabius ES (2001) Physiological effects of saline waters on zander. J Fish Biol 59:1544-1555

De Charleroy D, Grisez L, Thomas K, Belpaire C, Ollevier F (1990) The life cycle of Anguillicola crassus. Dis Aquat Org 8:77-84

Gallaugher P, Farrell AP (1998) Hematocrit and blood oxygen-carrying capacity. In: Perry SF, Tufts B (eds) Fish respiration. Academic Press, San Diego, CA

Gollock MJ (2002) The impact of Anguillicola crassus on the physiological stress response of the European eel. PhD thesis, University of Exeter, Exeter

Gollock MJ, Kennedy CR, Quabius ES, Brown JA (2004) The effect of parasitism of European eels with the nematode, Anguillicola crassus on the impact of netting and aerial exposure. Aquaculture 233:45-54

Greenwood AK, Butler PC, White RB, DeMarco U, Pearce D, Fernald RD (2003) Multiple corticosteroid receptors in a teleost fish: distinct sequences, expression patterns, and transcriptional activities. Endocrinology 144:4226-4236

Höglund J, Andersson J, Härdig J (1992) Haematological responses in the European eel, Anguilla anguilla L., to sublethal infestation by Anguillicola crassus in a thermal effluent of the Swedish Baltic. J Fish Dis 15:507-514 
Kelly CE (1998) Physiological stress responses of European eels (Anguilla anguilla) infected in the parasitic nematode Anguillicola crassus. PhD thesis, University of Exeter, Exeter

Kelly CE, Kennedy CR, Brown JA (2000) Physiological status of wild European eels (Anguilla anguilla) infected with the parasitic nematode, Anguillicola crassus. Parasitology 120:195-202

Kennedy CR, Fitch DJ, (1990) Colonization, larval survival and epidemiology of the nematode Anguillicola crassus, parasitic in the eel, Anguilla anguilla, in Britain. J Fish Biol 36:117-131

Kieffer JD, Alsop D, Wood CM (1998) A respirometric analysis of fuel use during aerobic swimming at different temperatures in rainbow trout (Oncorhynchus mykiss). J Exp Biol 201:3123-3133

Lee SJ, Lee JH, Kang JH, Lee JH, Min KS, Myung JI, Kim Y, Kong IS (2001) Effect of temperature shock on cultured olive flounder (Paralichthys olivaceus) and black rockfish (Sebastes schlegeli). J Fish Sci Technol 4:112-119

Lefebvre F, Contournet P, Crivelli AJ, (2002) The health state of the eel swimbladder as a measure of parasite pressure by Anguillicola crassus. Parasitology 124:457-463

Legate NJ, Bonen A, Moon TW (2001) Glucose tolerance and peripheral glucose utilization in rainbow trout (Oncorhynchus mykiss), American eel (Anguilla rostrata) and black bullhead catfish (Ameiurus melas). Gen Comp Endocrinol 122:48-59

Maule AG and VanderKooie SP (1999) Stress-induced immune-endocrine interactions. In: PHM Balm (ed) Stress physiology in animals. CRC Press, Boca Raton, FL, p 205-245

Mesa MG, Weiland LK, Wagner P (2002) Effects of acute thermal stress on the survival, predator avoidance, and physiology of juvenille fall chinook salmon. Northwest Sci 76: 118-128

Milligan CL (1997) The role of cortisol in amino acid mobilization and metabolism following exhaustative exercise in rainbow trout (Oncorhynchus mykiss Walbaum). Fish Physiol Biochem 16:119-128

Milligan CL, Wood CM (1982) Disturbances in haematology, fluid volume distribution and circulatory function associated with low environmental $\mathrm{pH}$ in the rainbow trout, Salmo gairdneri. J Exp Biol 99:397-415

Molnár K (1993) Effect of decreased oxygen content on eels (Anguilla anguilla) infected by Anguillicola crassus (Nematoda:Dranunculoidea). Acta Vet Hung 41:349-360

Editorial responsibility: Wolfgang Körting,

Hannover, Germany
Molnár K, Székely C, Baska F (1991) Mass mortality of eel in Lake Balaton due to Anguillicola crassus infection. Bull Eur Assoc Fish Pathol 11:211-212

Molnár K, Baska F, Csaba G, Glávatis R, Székely C (1993) Pathological and histopathological studies of the swimbladder of eels Anguilla anguilla infected by Anguillicola crassus (Nematoda: Dranunculoidea). Dis Aquat Org 15: $41-50$

Mommsen TP, Vijayan MM, Moon TW (1999) Cortisol in teleosts: dynamics, mechanisms of action and metabolic regulation. Rev Fish Biol Fish 9:211-268

Nikinmaa M, Salama A (1998) Oxygen transport in fish. In: Perry SF, Tufts B (eds) Fish respiration. Academic Press, San Diego, CA, p 141-184

Perry SF, Reid SD (1992) The relationship between b-adrenoceptors and adrenergic responsiveness in trout (Oncorhynchus mykiss) and eel (Anguilla rostrata) erythrocytes. J Exp Biol 167:235-250

Ryan SN (1995) The effect of chronic heat stress on cortisol levels in the Antarctic fish Pagothenia borchgrevinki. Experientia 51:768-774

Sébert P, Simon B, Barthélémy L (1995) Effects of a temperature increase on oxygen consumption of yellow freshwater eels exposed to high hydrostatic pressure. Exp Physiol 80: 1039-1046

Sures B, Knopf K, Kloas W (2001) Induction of stress by the swimbladder nematode Anguillicola crassus in European eels, Anguilla anguilla, after repeated experimental infection. Parasitology 123:179-184

Vijayan MM, Raptis S, Sathiyaa R (2003) Cortisol treatment affects glucocorticoid receptor and glucocorticoid-responsive genes in the liver of rainbow trout. Gen Comp Endocrinol 132:256-263

Wendelaar Bonga SE (1997) The stress response in fish. Physiol Rev 77:591-625

Wright PA, Perry SF, Moon TW (1989) Regulation of hepatic gluconeogenesis and glycogenolysis by catecholamines in rainbow trout during environmental hypoxia. J Exp Biol 147:169-188

Würtz J, Taraschewski H (2000) Histopathological changes in the swimbladder wall of the European eel Anguilla anguilla due to infections with Anguillicola crassus. Dis Aquat Org 39:121-134

Würtz J, Taraschewski H, Pelster B (1996) Changes in gas composition in the swimbladder of the European eel (Anguilla anguilla) infected with Anguillicola crassus (Nematoda). Parasitology 112:233-238

Submitted: July 6, 2004; Accepted: December 15, 2004

Proofs received from author(s): April 22, 2005 